\title{
Effect of carbon source on lipase production by Aeromonas sp. isolated from dairy effluent
}

\author{
Marcelo Rodrigues de Melo*, Thaise Celini Moraes, Cristiani Baldo da Rocha, Fabiana Guillen Moreira Gasparin, \\ Maria Antonia Pedrine Colabone Celligoi \\ From 5th Congress of the Brazilian Biotechnology Society (SBBIOTEC) \\ Florianópolis, Brazil. 10-14 November 2013
}

\section{Background}

Lipids are one of the major pollutants in domestic and industrial effluents. The use of lipases in the treatment of these effluents as well as in the bioremediation of contaminated environments represents an environmentally safe alternative to chemical methods [1]. Lipases (EC 3.1.1.3) are carboxylesterases that catalyze synthesis and hydrolysis of long-chain acylglycerols ( $>10$ carbons) and have great potential for industrial and biotechnological applications. Microorganisms are the major source for lipases and have advantages such as ease production and diversified enzymatic properties [2]. Effluents containing high concentrations of lipids represent a good source for the isolation of lipase producing microorganisms and dairy industries are responsible for production of large quantities of this of this kind of effluent [3]. In a previous study two lipase producing microorganisms were isolated from dairy effluents. This report presents the results of lipase production by these microorganisms in different carbon sources.

\section{Methods}

Isolates LODO 9 and LODO 10 were cultured overnight in DYG'S media $\left(28^{\circ} \mathrm{C}, 200 \mathrm{rpm}\right)$ and genomic DNA was extracted using AxyPrep ${ }^{\mathrm{TM}}$ Bacterial Genomic DNA Miniprep Kit (Axygen Biosciences) according to manufacturer recommendation. The $16 \mathrm{~S}$ rDNA was amplified from chromosomal DNA using primers fD1 (AGAGTTTGATCCTGGCTCAG) and rD1 (AAGGAGGTGATCCAGCC) for Escherichia coli K-12 [4]. The 16S rRNA gene sequences obtained were compared with sequences of other Aeromonas deposited in the GenBank database by using ClustalW program and a consensus neighbor-joining tree was constructed using Molecular Evolutionary Genetics Analysis (MEGA) Software Version 4.0 [5]. Isolates were grown $\left(30^{\circ} \mathrm{C}, 200 \mathrm{rpm}, 48 \mathrm{~h}\right)$ in minimal medium $(30$ $\mathrm{ml})$ containing $(\mathrm{g} / \mathrm{L}): \mathrm{NaNO}_{3}(4.0), \mathrm{KH}_{2} \mathrm{PO}_{4}(1.5) \mathrm{FeCl}_{3}$ (0.05), $\mathrm{MgSO}_{4}(0.2), \mathrm{CaCl}_{2}(0.01), \mathrm{Na}_{2} \mathrm{HPO}_{4}(0.5)$, yeast extract (0.05) and carbon source (10). Each carbon source (glucose, sucrose, lactose, cellobiose, xylose, glycerol, soybean oil, engine oil, diesel and gasoline) was tested separately from the other. The carbon source with best result was tested at concentrations of 0 to $250 \mathrm{~g} / \mathrm{L}$. The growth was accompanied by optical density at $600 \mathrm{~nm}$ and lipase activity by hydrolysis of $p \mathrm{NPP}\left(37^{\circ} \mathrm{C}, 10 \mathrm{~min}, 410\right.$ $\mathrm{nm}$ ). A lipase unit (U) was defined as $1 \mathrm{mmol}$ of pNP released per minute per $\mathrm{ml}$ supernatant under assay conditions.

\section{Results and conclusions}

Isolates were identified as Aeromonas sp. (Aeromonas sp. LODO 9 and Aeromonas sp. LODO 10) and phylogenetic analysis grouped both isolates together, closely to Aeromonas punctata ATCC 15468 . Lipase activity was detected only in cultures containing sucrose, cellobiose, glycerol, and soybean oil. The latter showed the best results with 95.02 and $87.80 \mathrm{U}$ for Aeromonas sp. LODO 9 and Aeromonas sp. LODO 10, respectively. Both isolates reached the maximum lipase activity with $50 \mathrm{~g} / \mathrm{L}$ of soybean oil. At this concentration of soybean oil, biomass and lipase activity of Aeromonas sp. LODO 9 were $6.38 \mathrm{mg} / \mathrm{mL}$ and 19.15 $\mathrm{U}$, respectively. At this same condition, biomass and lipase activity of Aeromonas sp. LODO 10 were $8.55 \mathrm{mg} / \mathrm{mL}$ and 202.22 U, respectively.

\section{Acknowledgements} CAPES/PNPD 
Published: 1 October 2014

\section{References}

1. Alcade $\mathrm{M}$, Ferrer M, Plou FJ, Ballesteros A: Environmental biocatalysis: from remediation with enzymes to novel green processes. Trends Biotechnol 2006, 24:281-287.

2. Jaeger KE, Dijkstra BW, REETZ MT: Bacterial Biocatalysts: molecular biology, three-dimensional structures, and biotechnological applications of lipases. Annu Rev Microbiol 1999, 53:315-351.

3. Rahman RNZRA, Leow TC, Salleh AB, Basri M: Geobacillus zalihae sp. nov a thermophilic lipolytic bacterium isolated from palm oil mill effluent in Malaysia. BMC Microbiol 2007, 7:77.

4. Weisburg WG, Barns SM, Pelletier DA, Lane DJ: 16S ribosomal DNA amplification for phylogenetic study. J Bacteriol 1991, 173:697-703.

5. Tamura K, Dudley J, Nei M, Kumar S: MEGA4: Molecular Evolutionary Genetics Analysis (MEGA) software version 4.0. Mol Biol Evol 2007, 24:1596-1599.

doi:10.1186/1753-6561-8-S4-P245

Cite this article as: de Melo et al: Effect of carbon source on lipase production by Aeromonas sp. isolated from dairy effluent. BMC

Proceedings 2014 8(Suppl 4):P245.

\section{Submit your next manuscript to BioMed Central} and take full advantage of:

- Convenient online submission

- Thorough peer review

- No space constraints or color figure charges

- Immediate publication on acceptance

- Inclusion in PubMed, CAS, Scopus and Google Scholar

- Research which is freely available for redistribution

Submit your manuscript at www.biomedcentral.com/submit 